\title{
Complement split product C5a mediates the lipopolysaccharide- induced mobilization of CFU-s and haemopoietic progenitor cells, but not the mobilization induced by proteolytic enzymes
}

\author{
W. J. Molendijk, A. van Oudenaren, H. van Dijk*, M. R. Daha† and \\ R. Benner \\ Department of Cell Biology, Immunology and Genetics, Erasmus University, Rotterdam, ${ }^{*}$ Immunology Section of \\ the Laboratory of Microbiology, State University of Utrecht, and $\dagger$ Department of Nephrology, University Hospital \\ Leiden, The Netherlands
}

(Received 12 September 1985; revision accepted 12 March 1986)

\begin{abstract}
Intravenous (i.v.) injection of mice with lipopolysaccharide (LPS), and the proteolytic enzymes trypsin and proteinase, mobilizes pluripotent haemopoietic stem cells (CFU-s) as well as granulocyte-macrophage progenitor cells (GM-CFU) and the early progenitors of the erythroid lineage (E-BFU) from the haemopoietic tissues into the peripheral blood. We investigated the involvement of the complement (C) system in this process. It appeared that the early mobilization induced by LPS and other activators of the alternative complement pathway, such as Listeria monocytogenes $(\mathrm{Lm})$ and zymosan, but not that induced by the proteolytic enzymes, was absent in $\mathrm{C} 5$-deficient mice. The mobilization by $\mathrm{C}$ activators in these mice could be restored by injection of C5-sufficient serum, suggesting a critical role for $\mathrm{C} 5$.

The manner in which $\mathrm{C} 5$ was involved in the $\mathrm{C}$ activation-mediated stem cell mobilization was studied using a serum transfer system. C5-sufficient serum, activated in vitro by incubation with $\mathrm{Lm}$ and subsequently liberated from the bacteria, caused mobilization in both C5-sufficient and C5-deficient mice. C5-deficient serum was not able to do so. The resistance of the mobilizing principle to heat treatment $\left(56^{\circ} \mathrm{C}\right.$, $30 \mathrm{~min}$ ) strongly suggests that it is identical with the C5 split product C5a, or an in vivo derivative of $\mathrm{C} 5 \mathrm{a}$. This conclusion was reinforced by the observation that a single injection of purified rat $\mathrm{C} 5 \mathrm{a}$ into $\mathrm{C} 5$-deficient mice also induced mobilization of CFU-s.
\end{abstract}

Haemopoietic stem cells (CFU's), granulocyte-macrophage progenitor cells (GM-CFU) and the early progenitor cells of erythrocytes (E-BFU) occur in the peripheral blood in extremely low numbers (Goodman \& Hodgson, 1962; Hara \& Ogawa, 1977; Rickard et al., 1971). Their frequency in the blood can be increased by intravenous (i.v.) injection of certain substances which stimulate their mobilization out of the haemopoietic tissues into the blood

Correspondence: Dr R. Benner, Department of Cell Biology, Immunology and Genetics, Erasmus University, P.O. Box 1738, 3000 DR Rotterdam, The Netherlands. 
stream. These substances include lipopolysaccharides (LPS), zymosan, proteolytic enzymes, polyanions and lectins (Vos, Buurman \& Ploemacher, 1972; Quesenberry et al., 1973; Ross et al., 1976; van der Ham, Benner \& Vos, 1977; Cline \& Golde, 1977; Vos \& Wilschut, 1979).

In mice, depending on the agent injected, peak CFU-s numbers are found 10 min to $6 \mathrm{hr}$ after injection. LPS and zymosan, in addition, cause a 'delayed' accumulation of CFU-s and haemopoietic progenitor cells in the peripheral blood and spleen, reaching peak numbers about 5 days after injection of the agent (Vos et al.,1972; Staber \& Johnson, 1980; Benner et al., 1981; Molendijk. Ploemacher \& Erkens-Versluis, 1982). Early CFU-s mobilization by LPS, zymosan and proteolytic enzymes, but not by polyanions, can be prevented by prior decomplementation with the complement (C) activating factor of cobra venom (CoF) (Wilschut et al.. 1979). LPS and zymosan are also incapable of early mobilization of CFU-s in complement C5-deficient mice (Benner et al., 1981). The delayed CFU-s accumulation in blood and spleen by these agents, on the other hand, was not affected in C5-deficient mice.

The experiments described in this paper were designed to explore the role of the $\mathrm{C}$ system in the early mobilization of CFU-s and haemopoietic progenitor cells by LPS and proteolytic enzymes in more detail. The results suggest that $\mathrm{C} 5 \mathrm{a}$ is the active principle in the LPS-induced mobilization of CFU-s and haemopoietic progenitor cells. C5a did not appear to be required for mobilization of the various types of colony-forming cells by proteolytic enzymes.

\section{MATERIALS AND METHODS}

\section{Mice and rats}

Male and female mice of the following strains were used: AKR (C5-deficient), DBA/2 (C5-deficient), (C3H/Law $\times \mathrm{DBA} / 2) \mathrm{F} 1$ (C5-sufficient), B10.D2/oSn (C5-deficient), B10.D2/nSn (C5-sufficient) and (C57BL/Rij $\times \mathrm{CBA} / \mathrm{Rij}) \mathrm{F} 1$ (C5-sufficient). The AKR, $\mathrm{DBA} / 2$ and $(\mathrm{C} 3 \mathrm{H} / \mathrm{Law} \times \mathrm{DBA} / 2) \mathrm{F} 1$ mice were purchased from the Radiobiological Institute TNO, Rijswijk, The Netherlands, B 10. D2/oSn mice from Jackson Laboratories, Bar Harbor, Maine, U.S.A., B10.D2/nSn mice from Bantin and Kingman, Aldbrough, U.K., and $(\mathrm{C} 57 \mathrm{BL} / \mathrm{Rij} \times \mathrm{CBA} / \mathrm{Rij}) \mathrm{Fl}$ mice from the Laboratory Animals Center of the Erasmus University. Rotterdam, The Netherlands. For the spleen colony assay male mice were used. The age of all donor and recipient mice ranged between 12 and 24 weeks. Lewis rats, 8-12 weeks old, were purchased from the Central Institute for the Breeding of Laboratory Animals TNO, Zeist. The Netherlands.

\section{Mobilizing agents}

LPS from Salmonella abortus equi was kindly provided by Dr C. Galanos, Max-Planck Institut für Immunobiologie, Freiburg, F.R.G. The properties and source of the proteinase and trypsin used were described previously (Vos et al., 1972; van der Ham et al., 1977; Vos \& Wilschut, 1979: Wilschut et al., 1979). Mobilizing agents were dissolved in pyrogen-free phosphate buffered saline (PBS). They were injected i.v. in a volume of $0.5 \mathrm{ml}$ PBS.

\section{Cell suspensions}

After killing the mice by exposure to carbon dioxide, blood samples were collected by cardiac puncture and immediately heparinized in plastic tubes containing preservative-free lithium heparin (Sigma. Detroit, Michigan, U.S.A.).

For cell culture. one volume of heparinized blood was mixed with one volume of $0.2 \%$ methylcellulose in $\alpha$-median ( $\alpha$-modification of Dulbecco minimal essential medium). Red blood cells were allowed to sediment for $30 \mathrm{~min}$ at room temperature. The leucocyte-rich 
plasma was pipetted off and the cells were washed twice in $\alpha$-medium containing $2 \%$ fetal calf serum (FCS).

\section{Cell culture}

Aliquots of $5 \times 10^{5}$ or $10^{6}$ nucleated blood cells were cultured in $35 \times 10 \mathrm{~mm}$ plastic tissue culture dishes at $37^{\circ} \mathrm{C}$ in a fully humidified incubator in an atmosphere of $5 \% \mathrm{CO}_{2}$ in air. The culture medium consisted of $\alpha$-medium supplemented with $0.8 \%$ methylcellulose, $1 \%$ de-ionized bovine serum albumin (No A-9647; Sigma, St. Louis, Missouri, U.S.A.), 10\% FCS, $10^{-4}$ M 2-mercaptoethanol (Merck-Schuchardt, Hohenbrunn, F.R.G.), 20\% mouse spleen Con A conditioned medium and 2.0 U of sheep plasma erythropoietin (Connaught Laboratories Ltd., Willowdale, Ontario, Canada). Granulocyte/macrophage colonies, containing at least 50 cells, were counted on day 7 of culture, erythroid bursts on day 10 . All cultures were done in triplicate.

\section{Irradiation}

Whole body irradiation was performed with a ${ }^{137} \mathrm{Cs}$ (Gammacell 40, Atomic Energy of Canada Ltd., Ottawa, Canada) at a dose rate of $1.29 \mathrm{~Gy} / \mathrm{min}$. (C57BL/Rij $\times \mathrm{CBA} / \mathrm{Rij}) \mathrm{F} 1$ mice received $9 \mathrm{~Gy}, \mathrm{AKR}$ and $(\mathrm{C} 57 \mathrm{BL} / 6 \mathrm{~J} \times \mathrm{DBA} / 2) \mathrm{F} 1$ mice $8 \cdot 5 \mathrm{~Gy}$.

\section{Spleen colony assay}

The spleen colony assay of Till \& McCulloch (1961) was performed as described previously (Molendijk et al., 1982). The spleens were taken out 8 days after irradiation and i.v. injection of the blood samples.

\section{Complement activation in vitro}

For the in vitro activation of $\mathrm{C}$, mouse or rat serum was used from non-heparinized blood that was allowed to clot for $90 \mathrm{~min}$ at room temperature. One $\mathrm{ml}$ of serum was mixed with $0.5 \mathrm{ml}$ of saline containing $3.2 \times 10^{9}$ heat-inactivated $\left(56^{\circ} ; 60 \mathrm{~min}\right) L$. monocytogenes bacteria. This mixture was incubated for $30 \mathrm{~min}$ at $37^{\circ} \mathrm{C}$. After incubation the bacteria were pelleted by centrifugation at 5000 r.p.m. for $10 \mathrm{~min}$ at $4^{\circ} \mathrm{C}$. The remaining bacteria were removed from the supernatant by filtration through a $0.22 \mu \mathrm{m}$ filter (Millipore, Bedford, Massachusetts, U.S.A.). Control serum from the same bleeding was mixed with saline only, but otherwise similarly treated.

\section{Heat inactivation of complement}

Mouse serum was heat-decomplemented by incubation in a waterbath for $30 \mathrm{~min}$ at $56^{\circ} \mathrm{C}$.

\section{Assay for alternative complement pathway activity}

The alternative complement pathway activity of the serum samples activated by L. monocytogenes bacteria was determined as described previously (van Dijk, Rademaker \& Willers, 1980; van Kessel et al., 1981).

\section{Purification of rat C5a}

One hundred and seventy five $\mathrm{ml}$ of fresh rat plasma collected in $2 \mathrm{~mm}$-EDTA, $1 \mathrm{unit} / \mathrm{ml}$ of trasylol, $2 \mathrm{mM}$ benzamidine and $0.5 \mathrm{mM}$ fluryl-methyl-sulphonyl fluoride (PMSF) was precipitated with a final concentration of $6 \%$ polyethyleneglycol- 6000 during 60 min at $0^{\circ} \mathrm{C}$. After centrifugation $(15 \mathrm{~min}, 5000 \mathrm{~g}$ ) the precipitate was dissolved in $35 \mathrm{ml}$ Tris- $\mathrm{HCl}$ buffer $(0.01 \mathrm{M}$ Trizma base, containing the above mentioned inhibitors and adjusted to a $\mathrm{PH}$ of 7.8 with $\mathrm{HCl}$ ) dialyzed overnight at $4^{\circ} \mathrm{C}$ against the same buffer, and applied on a $1.5 \times 45 \mathrm{~cm}$ DEAE Sephacel column which was equilibrated in dialysis buffer. After collection of 
50 fractions of $5 \mathrm{ml}$ each, bound C5 was eluted using a linear salt gradient. The C 5 haemolytic activity (Daha et al., 1982), which was eluted from the column with a conductivity between 6 and $8 \mathrm{mS}$, was pooled, dialyzed against $0.01 \mathrm{M}$ acetate buffer, $\mathrm{pH} 6.3$ and subjected to cation-exchange chromatography of a $1.5 \times 20 \mathrm{~cm}$ Sulphopropyl-C50 column. C5 haemolytic activity. eluted from the column with a linear salt gradient and found between 3 and $5 \mathrm{mS}$, was concentrated to a volume of $5 \mathrm{ml}$ and subjected to gelfiltration on a $2.5 \times 90 \mathrm{~cm}$ Sephacryl S300 column. C5 haemolytic activity which filtered with an apparent molecular weight of 185,000 daltons was pooled and applied on a column of Sepharose 4B to which anti-rat-C3 and anti-rat-H were coupled (Daha et al., 1979; Daha \& van Es, 1982) to remove minor contaminants of rat-C3 and rat-H from the $\mathrm{C} 5$ preparation. The final $\mathrm{C} 5$ preparation was homogeneous on SDS-PAGE analysis.

To obtain C5a, $3 \mathrm{mg}$ purified $\mathrm{C} 5$ an isotonic Veronal buffered saline was reacted during $60 \mathrm{~min}$ at $37^{\circ} \mathrm{C}$ with $1 \times 10^{\circ}$ intermediates bearing the classical pathway C 5 convertase EAC1423 (Daha, Hazevoet \& Van Es, 1983). The intermediates were then removed by centrifugation and the small molecular weight $\mathrm{C} 5 \mathrm{a}$ was obtained by gelfiltration on Sephadex-G75. The final material was dialysed against distilled $\mathrm{H}_{2} \mathrm{O}$, freeze-dried and finally resuspended in $2 \mathrm{ml}$ pyrogen-free $0.15 \mathrm{M} \mathrm{NaCl}$.

\section{RESULTS}

\section{Mobilization of CFU-s, GM-CFU and E-BFU in C5-deficient mice by LPS}

Complement C5-deficient mice, e.g. DBA/2, B10.D2/oSn and AKR (Cinader, Dubiski \& Wardlaw, 1964; Rosen, 1975), are incapable of CFU-s mobilization upon i.v. injection of LPS (Benner et al., 1981). We investigated whether the mobilization of GM-CFU and E-BFU is similarly defective in C5-deficient mice. Therefore, C5-deficient DBA/2, B10.D2/oSn and AKR mice and genetically related, C5-sufficient $(\mathrm{C} 3 \mathrm{H} \times \mathrm{DBA} / 2) \mathrm{F} 1$ mice and $\mathrm{B} 10 . \mathrm{D} 2 / \mathrm{nSn}$ mice were injected with LPS or PBS. In the control mice, injection of LPS led to the mobilization of CFU-s as well as GM-CFU and E-BFU (Table 1). The increase in GM-CFU and E-BFU numbers was proportionally smaller than that of CFU-s. In the C5-deficient mice, mobilization of all three cell types was weak or absent (Table 1). The data from the C5-sufficient and C5-deficient mouse strains differ significantly $(P<0.0001)$.

\section{Mobilization of CFU-s in C5-deficient mice by proteolytic enzymes}

Injection of $\mathrm{C} 5$-deficient mice with the proteolytic enzymes trypsin and proteinase did induce mobilization of CFU-s into the peripheral blood. Both enzymes were found to cause a dose dependent increase of blood CFU-s numbers in normal as well as C5-deficient mice (Table 2).

\section{Mobilization of CFU-s in C5-deficient mice injected with C5-sufficient serum \\ Injection of C5-deficient DBA/2 mice with $1 \mathrm{ml}$ serum from C5-sufficient (C57BL $\times$ CBA)F 1 mice enabled these DBA/2 mice to respond to injection of LPS with CFU-s mobilization. DBA/ 2 mice, injected with $300 \mu \mathrm{g}$ LPS i.v. 1 hr after infusion of the C5-sufficient serum, had $306 \pm 100 \mathrm{CFU}-\mathrm{s} / \mathrm{ml}$ blood at $30 \mathrm{~min}$ after LPS injection, whereas control DBA $/ 2$ mice injected with the same amount of LPS had $64 \pm 19$ CFU-s $/ \mathrm{ml}$ blood.}

\section{CFU-s mobilization by serum-containing activated complement}

The fact that LPS is an activator of the alternative $C$ pathway, and the observation that LPS-induced CFU-s mobilization is absent in decomplemented and C5-deficient mice, suggest that activation of $\mathrm{C} 5$ via the alternative $\mathrm{C}$ pathway may be important for the LPS-induced 
Table 1. Mobilization of CFU-s, GM-CFU and E-BFU by LPS in the C5-deficient mouse strains DBA/2, B 10.D2/oSn and AKR

\begin{tabular}{|c|c|c|c|c|c|c|c|}
\hline \multirow[b]{2}{*}{ Mouse strain } & \multirow[b]{2}{*}{$\mathrm{C} 5 \dagger$} & \multicolumn{2}{|c|}{ CFU-s/ml blood* } & \multicolumn{2}{|c|}{ GM-CFU/ml blood } & \multicolumn{2}{|c|}{ E-BFU $/ \mathrm{ml}$ blood } \\
\hline & & PBS & LPS & PBS & LPS & PBS & LPS \\
\hline $\mathrm{DBA} / 2$ & - & $42 \pm 4 \ddagger$ & $72 \pm 4$ & $43 \pm 5$ & $80 \pm 6$ & $20 \pm 2$ & $19 \pm 4$ \\
\hline \multirow[t]{2}{*}{$(\mathrm{C} 3 \mathrm{H} \times \mathrm{DBA} / 2) \mathrm{F} 1$} & + & $16 \pm 3$ & $730 \pm 61$ & $86 \pm 9$ & $664 \pm 39$ & $104 \pm 13$ & $284 \pm 15$ \\
\hline & & $21 \pm 6$ & $1000 \pm 88$ & $50 \pm 3$ & $532 \pm 28$ & $13 \pm 2$ & $93 \pm 7$ \\
\hline \multirow[t]{2}{*}{ B $10 . \mathrm{D} 2 / \mathrm{oSn}$} & - & $44 \pm 5$ & $72 \pm 10$ & $78 \pm 9$ & $42 \pm 13$ & $14 \pm 6$ & $14 \pm 3$ \\
\hline & & $40 \pm 7$ & $92+5$ & $23 \pm 2$ & $18 \pm 2$ & & \\
\hline \multirow{2}{*}{ B 10.D2/nSn } & + & $48 \pm 5$ & $760 \pm 92$ & $75 \pm 9$ & $259 \pm 7$ & $24 \pm 5$ & $61 \pm 6$ \\
\hline & & $51 \pm 5$ & $594 \pm 45$ & $110 \pm 19$ & $779 \pm 29$ & & \\
\hline \multirow[t]{2}{*}{$\mathrm{AKR}$} & - & $52 \pm 7$ & $21 \pm 7$ & $14 \pm 5$ & $17 \pm 3$ & $9 \pm 4$ & $8 \pm 2$ \\
\hline & & $29 \pm 4$ & $80 \pm 4$ & $18 \pm 8$ & $12 \pm 5$ & $16 \pm 6$ & $20 \pm 4$ \\
\hline
\end{tabular}

* Blood was taken 30 min after i.v. injection of $300 \mu \mathrm{g}$ LPS or $0.5 \mathrm{ml}$ PBS.

$\dagger$ C 5-sufficient mouse strains are indicated by + , C5-deficient mouse strains by - .

$\ddagger$ Arithmetic mean \pm SEM.

Table 2. CFU-s mobilization by trypsin and proteinase in the C5-deficient mouse strains DBA/2, B10.D2/oSn and $\mathrm{AKR}$

\begin{tabular}{|c|c|c|c|c|c|c|}
\hline \multirow[b]{2}{*}{ Mouse strain } & \multirow[b]{2}{*}{$\mathrm{C} 5^{\dagger}$} & \multirow[b]{2}{*}{ PBS } & \multicolumn{4}{|c|}{ CFU-s/ml blood* } \\
\hline & & & $\begin{array}{l}0.4 \mathrm{mg} \\
\text { trypsin }\end{array}$ & $\begin{array}{l}2.0 \mathrm{mg} \\
\text { trypsin }\end{array}$ & $\begin{array}{c}0.1 \mathrm{mg} \\
\text { proteinase }\end{array}$ & $\begin{array}{c}0.5 \mathrm{mg} \\
\text { proteinase }\end{array}$ \\
\hline \multirow{2}{*}{$\mathrm{DBA} / 2$} & - & $46 \pm 8$ & $119 \pm 9$ & $367 \pm 97$ & $150 \pm 44$ & $640 \pm 65$ \\
\hline & & $52 \pm 11$ & $71 \pm 9$ & $100 \pm 7$ & $319 \pm 20$ & $594 \pm 43$ \\
\hline \multirow[t]{2}{*}{$(\mathrm{C} 3 \mathrm{H} \times \mathrm{DBA} / 2) \mathrm{Fl}$} & + & $45 \pm 7$ & $89 \pm 48$ & $240 \pm 112$ & $209 \pm 38$ & $570 \pm 65$ \\
\hline & & $16 \pm 3$ & $45 \pm 12$ & $160 \pm 32$ & $404 \pm 15$ & $547 \pm 58$ \\
\hline \multirow{2}{*}{$\mathrm{B} 10 . \mathrm{D} 2 / \mathrm{oSn}$} & - & $37 \pm 9$ & $30+8$ & $143 \pm 52$ & $81 \pm 8$ & $381 \pm 37$ \\
\hline & & $40 \pm 7$ & $91 \pm 11$ & $160 \pm 21$ & $216 \pm 18$ & $405 \pm 22$ \\
\hline \multirow[t]{2}{*}{ B10.D2/nSn } & + & $53 \pm 6$ & $81 \pm 11$ & $90 \pm 29$ & $186 \pm 9$ & $440 \pm 40$ \\
\hline & & $48 \pm 5$ & $97 \pm 6$ & $180 \pm 16$ & $187 \pm 13$ & $400 \pm 32$ \\
\hline \multirow{2}{*}{ AKR } & - & $52 \pm 7$ & $61 \pm 6$ & $106 \pm 14$ & $150 \pm 22$ & $586 \pm 74$ \\
\hline & & $29 \pm 4$ & $142 \pm 8$ & $180 \pm 16$ & $300 \pm 18$ & $686 \pm 78$ \\
\hline
\end{tabular}

* Blood was taken 30 min after i.v. injection of trypsin, proteinase or PBS.

$+\mathrm{C} 5$-sufficient mouse strains are indicated by,$+ \mathrm{C} 5$-deficient mouse strains by - .

$\ddagger$ Arithmetic mean \pm SEM.

CFU-s mobilization. To investigate this putative mediatory role of $\mathrm{C}$, normal mouse serum (NMS) was incubated in vitro with Listeria monocytogenes $(\mathrm{Lm})$ which has also been shown to activate $C$ via the alternative pathway (Van Kessel et al., 1981). C activation was measured by determining the remaining alternative pathway $C$ activity (van Dijk et al., 1980). Figure 1 shows that in vitro incubation of $(\mathrm{C} 57 \mathrm{BL} \times \mathrm{CBA}) \mathrm{FI}$ serum with $\mathrm{Lm}$ led to a complete $\mathrm{C}$ consumption as determined in the haemolytic assay. Neither before nor after incubation with $L m$ did the serum of C5-deficient mice show haemolytic activity.

Injection of mice with $L m$-treated serum from $C 5$-sufficient mice was found to cause a 4to 7 -fold increase in the blood CFU-s numbers within $30 \mathrm{~min}$ (Table 3). Serum which had been heat-inactivated $\left(30 \mathrm{~min} 56^{\circ} \mathrm{C}\right)$ to destroy the $\mathrm{C}$ enzymes and subsequently incubated 


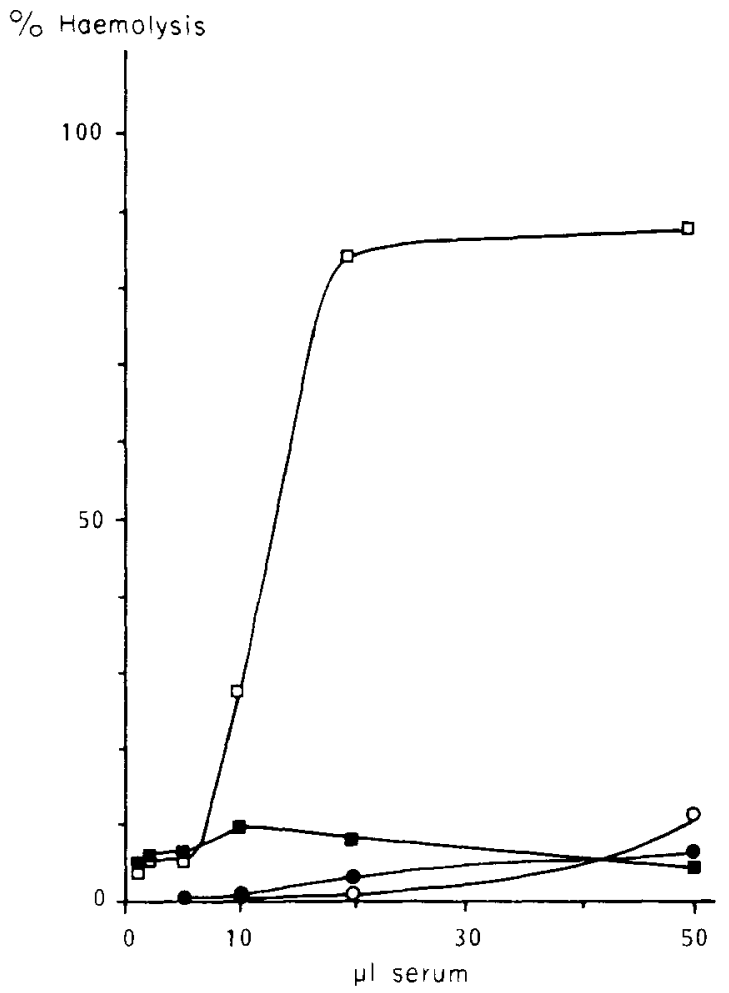

Fig. 1. Haemolytic complement activity of normal (C57BL $\times$ CBA)F1 ( $\square$ ) and DBA/2 (O) serum, and Lm-activated (C57BL $\times$ CBA)F $1(\mathbf{D})$ and DBA/2 (O) serum.

Table 3. CFU-s mobilization by Listeria-treated normal mouse serum

\begin{tabular}{|c|c|c|c|c|c|c|}
\hline \multirow[b]{2}{*}{ Serum donor } & \multirow[b]{2}{*}{$\mathrm{Cst}$} & \multirow[b]{2}{*}{ Recipient } & \multirow[b]{2}{*}{$\mathrm{C} 5+$} & \multicolumn{3}{|c|}{ CFU-s/ml blood* } \\
\hline & & & & NMS $\ddagger$ & $L m$-NMS & INACT- $L m$-NMS \\
\hline \multirow[t]{2}{*}{$(\mathrm{C} 57 \mathrm{BL} \times \mathrm{CBA}) \mathrm{Fl}$} & + & $(\mathrm{C} 57 \mathrm{BL} \times \mathrm{CBA}) \mathrm{Fl}$ & + & $87 \pm 58$ & $326 \pm 13$ & $85 \pm 9$ \\
\hline & & & & $26 \pm 7$ & $304 \pm 22$ & $46 \pm 6$ \\
\hline \multirow[t]{2}{*}{$\mathrm{DBA} / 2$} & - & $(\mathrm{C} 57 \mathrm{BL} \times \mathrm{CBA}) \mathrm{F} 1$ & + & $73 \pm 8$ & $92 \pm 7$ & $92 \pm 4$ \\
\hline & & & & $59 \pm 4$ & $61 \pm 6$ & \\
\hline \multirow[t]{2}{*}{ AKR } & - & $(\mathrm{C} 57 \mathrm{BL} \times \mathrm{CBA}) \mathrm{F} 1$ & + & $55 \pm 7$ & $56 \pm 6$ & $79 \pm 6$ \\
\hline & & & & $78 \pm 6$ & $90 \pm 5$ & $160 \pm 6$ \\
\hline \multirow[t]{2}{*}{$(\mathrm{C} 57 \mathrm{BL} \times \mathrm{CBA}) \mathrm{F} l$} & + & $\mathrm{DBA} / 2$ & - & $149 \pm 10$ & $669 \pm 22$ & $128 \pm 4$ \\
\hline & & & & $105 \pm 11$ & $695 \pm 48$ & $118 \pm 9$ \\
\hline
\end{tabular}

* Blood was taken $30 \mathrm{~min}$ after i.v. injection of $0.75 \mathrm{ml}$ serum.

$+\mathrm{C} 5$-sufficient mouse strains are indicated by + . C 5 -deficient mouse strains by - .

I. NMS means normal mouse serum; $L m$-NMS means NMS incubated with Listeria bacteria; INACT- $L m$ NMS means NMS from which the complement enzymes were inactivated by treatment for $30 \mathrm{~min}$ at $56^{\circ} \mathrm{C}$ and was subsequently incubated with Listeria bacteria.

$\S$ Arithmetic mean \pm SEM. 
with $L m$ had no significant activity. $L m$-treated serum from C5-deficient DBA/2 and AKR mice could not cause an increase in the blood CFU-s numbers.

Since the observed CFU-s mobilization in C5-sufficient mice injected with $\mathrm{Lm}$-treated NMS might be due to activation of the recipients $C$ system, we also injected C5-deficient DBA-2 mice with $L m$-treated C5-sufficient (C57BL $\times$ CBA)F 1 serum. Also under these conditions, $L m$-treated serum caused CFU-s mobilization (Table 3 ). The somewhat increased numbers of CFU-s in the peripheral blood of the NMS-infused control mice are at the upper limit of the normal range found in untreated control mice. As to the normal variation in background circulating CFU-s numbers, in each experiment a control group was included from the same supplier and delivery.

Not only $L m$-activated NMS mobilized CFU-s, but also $L m$-activated normal rat serum was able to do so. This is shown in Table 4 for Lewis rat serum infused in C5-deficient DBA/2 mice.

$\mathrm{C} 5 \mathrm{a}$, in contrast to most other $\mathrm{C}$ components, including native $\mathrm{C5}$, is resistent to heat-inactivation for $30 \mathrm{~min}$ at $56^{\circ} \mathrm{C}$ (Hugli \& Müller-Eberhard, 1978). We made use of this property to determine whether C5a may be the intermediate in the LPS-induced mobilization of CFU-s. Indeed, NMS from C5-sufficient mice that had been incubated with $L m$, and subsequently heat-inactivated, was still able to mobilize CFU-s. This was found in C5-sufficient $(\mathrm{C} 57 \mathrm{BL} \times \mathrm{CBA}) \mathrm{F} 1$ recipients as well as in $\mathrm{C5}$-deficient $\mathrm{DBA} / 2$ recipients (Table 5).

Table 4. CFU-s mobilization by Listeria-treated rat serum

\begin{tabular}{|c|c|c|c|c|c|c|}
\hline \multirow[b]{2}{*}{ Serum donor } & \multirow[b]{2}{*}{$\mathrm{Cs}^{+}$} & \multirow[b]{2}{*}{ Recipient mice } & \multirow[b]{2}{*}{$\mathrm{C} 5{ }^{\dagger}$} & \multicolumn{3}{|c|}{ CFU-s/ml blood* } \\
\hline & & & & PBS & NRaSt & $L m-\mathrm{NRaS}$ \\
\hline Lewis rat & + & $\mathrm{DBA} / 2$ & - & $27 \pm 6 \S$ & $25 \pm 6$ & $270 \pm 48$ \\
\hline
\end{tabular}

* Blood samples were taken 30 min after i.v. injection of $0.75 \mathrm{ml}$ serum.

$\dagger$ Lewis rats are C5-sufficient, DBA/2 mice are C5-deficient.

$\ddagger \mathrm{NRaS}$ means normal rat serum; $L m$-NRaS means $\mathrm{NRaS}$ that has been incubated with $L i$ isteria bacteria.

$\S$ Arithmetic mean \pm SEM.

Table 5. CFU-s mobilization by heat inactivated Listeria-treated normal mouse serum

\begin{tabular}{|c|c|c|c|c|c|c|}
\hline \multirow[b]{2}{*}{ Serum donor } & \multirow[b]{2}{*}{$\mathrm{C} 5{ }^{\dagger}$} & \multirow[b]{2}{*}{ Recipient } & \multirow[b]{2}{*}{$\mathrm{C}^{+}{ }^{+}$} & \multicolumn{3}{|c|}{ CFU-s/Ml blood* } \\
\hline & & & & NMS $\ddagger$ & $L m$-NMS & $L m$-NMS-INACT \\
\hline \multirow[t]{2}{*}{$(\mathrm{C} 57 \mathrm{BL} \times \mathrm{CBA}) \mathrm{F} 1$} & + & $(\mathrm{C} 57 \mathrm{BL} \times \mathrm{CBA}) \mathrm{F} 1$ & + & $86 \pm 7 \S$ & $495 \pm 21$ & $333 \pm 17$ \\
\hline & & & & $124 \pm 8$ & $686 \pm 28$ & $630 \pm 20$ \\
\hline \multirow[t]{3}{*}{$(\mathrm{C} 57 \mathrm{BL} \times \mathrm{CBA}) \mathrm{F} 1$} & + & $\mathrm{DBA} / 2$ & - & $24 \pm 7$ & $146 \pm 18$ & $172 \pm 35$ \\
\hline & & & & $23 \pm 5$ & $197 \pm 38$ & $172+38$ \\
\hline & & & & $21 \pm 14$ & $368 \pm 38$ & $225 \pm 74$ \\
\hline
\end{tabular}

* Blood samples were taken 30 min after i.v. injection of $0.75 \mathrm{ml}$ serum.

† C5-sufficient mouse strains are indicated by,+ C5-deficient mouse strains by - .

$\ddagger$ NMS means normal mouse serum; $L m$-NMS means NMS incubated with Listeria bacteria; $L m$-NMSINACT means NMS that was incubated with Listeria bacteria and was subsequently treated for 30 min at $56^{\circ} \mathrm{C}$ to inactivate the complement enzymes, except C5a.

$\S$ Arithmetic mean \pm SEM. 


\section{CFU-s mobilization by purified rat C5a}

The possible mediatory role of $\mathrm{C} 5 \mathrm{a}$ in murine CFU-s mobilization was further analysed by infusing $\mathrm{C} 5$-deficient $\mathrm{DBA} / 2$ mice with purified rat $\mathrm{C} 5 \mathrm{a}$. Rat C5a was used because no isolation procedures are available for mouse $\mathrm{C} 5 \mathrm{a}$, as yet. It was found that purified rat $\mathrm{C} 5 \mathrm{a}$ caused a dose-dependent accumulation of CFU-s in the peripheral blood (data not shown). After i.v. injection of $25 \mu \mathrm{g}$ purified rat C5a, maximum numbers of circulating CFU-s were found after 15 to 30 min (Table 6). The peak numbers of CFU-s induced by purified rat C5a were of the same order of magnitude as those caused by injection of C 5 -sufficient mice with LPS or by injection of $L m$-activated NMS or $L m$-activated normal rat serum (c.f. Tables 1,3 and 4).

Table 6. CFU-s mobilization in C5-deficient DBA/2 mice injected with purified rat C5a

\begin{tabular}{lccccc}
\hline & \multicolumn{5}{c}{ Min after injection of purified rat C5a* } \\
\cline { 2 - 5 } \multicolumn{1}{c}{ PBS } & 5 & 15 & 30 & 60 & 120 \\
\hline $61 \pm 11^{+}$ & $160 \pm 32$ & $323 \pm 60$ & $240 \pm 56$ & $218 \pm 53$ & $95 \pm 15$ \\
$26 \pm 4$ & $68 \pm 17$ & $222 \pm 39$ & $399 \pm 113$ & $230 \pm 38$ & $52 \pm 8$ \\
$P$ value $\ddagger$ & $P=0.030$ & $P=0.0024$ & $P=0.014$ & $P=0.011$ & $P=0.035$ \\
\hline
\end{tabular}

- Blood samples were taken at the indicated intervals after i.v. injection of $25 \mu \mathrm{g}$ purified rat C5a.

+ Figures represent the arithmetic mean \pm 1 SEM of the number of CFU-s per ml blood.

$\mp P$-values (calculated by the two-sided Student $t$-test) refer to comparison of the figures found at the various intervals after injection of rat C5a and the figures obtained after injection of PBS.

\section{DISCUSSION}

A variety of studies show that i.v. injection of mice with bacterial LPS induces the mobilization of CFU-s from the haemopoietic tissues into the peripheral blood within minutes of injection (Vos et al., 1972; Vos \& Wilschut, 1979). This early mobilization is not restricted to CFU-s since more mature cell types are also mobilized, although not all to the same extent (Ploemacher et al., 1980). The present studies extend these observations by showing that GM-CFU and E-BFU are also rapidly mobilized by LPS. It can thus be concluded that the early LPS-induced mobilization of haemopoietic cells neither has cell-type specificity nor is restricted to particular differentiation stages.

In a previous paper we have concluded that the $C$ system is involved in the early LPS-induced mobilization of CFU-s, since LPS-induced CFU-s mobilization is deficient in mice that have been pre-treated with CoF (Wilschut et al., 1979) and also in C5-deficient mice (Benner et al., 1981). In the present paper it appears that this role of the $\mathrm{C}$ system is not restricted to the mobilization of CFU-s. The mobilization of GM-CFU, E-BFU (Table 1) and mature cell types (data not shown) is also highly defective in C5-deficient mice. This suggests that $C$ is involved in the LPS-induced mobilization of all types of haemopoietic cells.

In the LPS-non-responder mouse strains $\mathrm{C} 3 \mathrm{H} / \mathrm{HeJ}$ and $\mathrm{C} 57 \mathrm{BL} / 10 . \mathrm{ScCr}$, which lack a serologically identifiable structure ('LPS-receptor') that is present in all LPS-responder strains (Forni \& Coutinho, 1978), the late but not the early mobilization of CFU-s upon LPS injection is absent (Benner et al., 1981). Together with the above data concerning the role of $\mathrm{C}$, this observation suggests that not the LPS-receptor, but one or more $\mathrm{C}$ components may 
be the active principle(s) which account for the rapid mobilization of haemopoietic cells after LPS injection.

In the present paper we show that in vitro activation of C5-sufficient NMS and normal rat serum by $L m$ leads to the formation of product(s) that can induce CFU-s mobilization in C5-deficient mice (Table 3 and 4). Such $L m$-activated serum is still active after heat-inactivation for $30 \mathrm{~min}$ at $56^{\circ} \mathrm{C}$ (Table 3). As C5a and its nonspecific helper factor, in contrast to most other $\mathrm{C}$ components, are resistant to heat inactivation (Hugli \& Müller-Eberhard, 1978; Perez \& Goldstein, 1981), this observation suggests that C5a or an in vivo derivative of C5a is the active principle in the LPS-induced early mobilization of CFU-s and haemopoietic progenitor cells. This might be related to the chemotactic activity of C5a (Snyderman et al., 1969; Fernandez et al., 1978), supposing that CFU-s and haemopoietic progenitor cells have a binding site for this fragment.

Recent data suggest that spleen colonies measured at 7-8 days after i.v. injection of CFU-s and colonies measured on days 12-13 are derived from (partly) different subpopulations of CFU-s (Bertoncello, Hodgson \& Bradley, 1985). As we determined the spleen colonies on day 8 only, the data presented refer to this particular subpopulation only. It would be of interest to investigate whether CFU-s that give rise to days 12-13 colonies behave similarly.

The mechanism of translation of such a chemotactic stimulus is not entirely known. When the active substance reaches the surface of the cell, an esterase is activated and the hexosemonophosphate shunt is stimulated. Subsequently, calcium enters the cytoplasm and the cytoplasmic contractile proteins assemble (Loor, 1980). Thus, both the energy and the means required for the movement of the cell are provided.

Alternatively, the haemopoietic cells might be sent passively into the circulation, being brought about by other cells which are known to be susceptible to the chemotactic activity of C5a, such as neutrophils and macrophages (Snyderman et al., 1969; Snyderman, Shin \& Hauseman, 1971). Furthermore, it cannot be excluded that the mobilization by C5a is mediated by its property to induce contraction of smooth muscle, or the fact that it is an anaphylatoxin inducing the release of histamine from mast cells and basophils (Hugli \& Müller-Eberhard, 1978), which may lead to increased vascular permeability.

It is remarkable that the mobilization of CFU-s and haemopoietic progenitor cells by trypsin and proteinase is not decreased in C5-deficient mice, since previous studies have shown that decomplementation of mice by high doses of CoF does inhibit CFU-s mobilization by these enzymes (Wilschut et al., 1979). Proteolytic enzymes, however, have been shown to activate C3 directly (Bokisch, Müller-Eberhard \& Cocchrane, 1969; Molenaar et al., 1974), so that the effects of these enzymes on CFU-s mobilization in C5-deficient mice are most likely to be explained by $\mathrm{C} 3$-activation and, consequently, release of $\mathrm{C} 3 \mathrm{a}$, which is also an anaphylatoxin, but which has only limited chemotactic activity (Snyderman et al., 1969; Hugli \& Müller-Eberhard, 1978). The inability of CoF-treated mice to respond to trypsin and proteinase is probably due to exhaustion of $\mathrm{C} 3$ (as well as later components of the $\mathrm{C}$ cascade), so that CoF-treated mice cannot generate $\mathrm{C} 3 \mathrm{a}$ and $\mathrm{C} 5 \mathrm{a}$, and thus cannot mobilize CFU-s.

\section{ACKNOWLEDGMENTS}

We gratefully acknowledge Professor Dr O. Vos for his continuous support, Mrs M. Stout for typing the manuscript and the Netherlands Foundation for Medical Research (FUNGO) for their financial support. 


\section{REFERENCES}

BenNer. R.. Rijnbeek. A.M.. MolendiJk. W. \& Vos. O. (1981) Genetic control of lipopolysaccharide-induced mobilization of CFU-s. Cell Tissue Kinet. 14. 143.

Bertoncello. I. Hodgson. G.S. \& Bradley. T.R. (1985) Multiparameter analysis of transplantable hemopoietic stem cells: I. The separation and enrichment of stem cells homing to marrow and spleen on the basis of Rhodamine-123 fluorescence. Exp. hematol. 13. 999.

Bokisch. V.A.. MÜller-Ebermard. H.J. \& Cocchrane. C.G. (1969) Isolation of a fragment (C3a) of the third component of human complement containing anaphylatoxin and chemotactic activity and description of an anaphylatoxin inactivator of human serum. J. Exp. Med. 129, 1109.

Cinader. B.. Dubiski. S. \& Wardlaw. A.C. (1964) Distribution. inheritance and properties of an antigen, MUB1. and its relation to hemolytic complement. J. Exp. Med. 120,897.

Cline. M.J. \& GoldE. D.W. (1977) Mobilization of hemopoietic stem cells (CFU-C) into the peripheral blood of man by endotoxin. Exp. Hematol. 5. 186.

Daha, M.R., Bertina. R.M.. Thompson. J., Kaufmann. R.H., Nicholson-Weller, A.. Veltkamp, J.J. \& BRIËT. E. (1982) Combined hereditary deficiency of the sixth component of complement and factor VIII coagulant activity in a Dutch family. Clin. Exp. Immunol. $48,733$.

Daha. M.R. HAzeVoet. H.M. \& VAN Es. L.A. (1983) Regulation of immunecomplex-mediated complement activation by autoantibodies (F-42) isolated from sera of patients with systemic lupus erythematosus. Clin. Exp. Immunol. 53. 541.

Daha. M.R.. Stuffers-Heiman. M. KiJlstra. A. \& van Es. L.A. (1979) Isolation and characterization of the third component of rat complement. J. Immunol. 36. 63.

DAHA. M.R. \& VAN Es. L.A. (1982) Isolation. characterization and mechanism of action of rat $\beta 1$ H. J. Immunol. 128. 1839.

vaN Dijk. H. Rademaker. P.M. \& Willers, J.M.N. (1980) Determination of alternative pathway of complement activity in mouse serum using rabbit erythrocytes. J. Immunol. Meth. 36, 29.

Fernandez. H.N.. Henson. P.M.. Otani. A. \& Hugli. T.E. (1978) Chemotactic response to human C3a and $\mathrm{C} 5 \mathrm{a}$ anaphylatoxins. I. Evaluation of $\mathrm{C} 3 \mathrm{a}$ leukotaxis in vitro and under stimulated in vivo conditions. $J$. Immunol. 120. 109.

Forin. L. \& Courinho. A. (1978) An antiserum which recognizes lipopolysaccharide-reactive B cells in the mouse. Eur. J. Immunol. 8.56.

Goodman. J.W. \& Hodgson. G.S. (1962) Evidence for stem cells in the peripheral blood of mice. Blood, 19. 702.

VAN der HaM. A.C.. BeNNer. R. \& VOS. O. (1977) Mobilization of B and T lymphocytes and haemopoietic stem cells by polymethacrylic acid and dextran sulphate. Cell Tissue Kinet. 10, 387.

Hara. M. \& OGawa. M. (1977) Erythropoietic precursors in murine blood. Exp. Hematol. 5. 161.

HLGli. T.E. \& Müller-Eberhard. M.S. (1978) Anaphylatoxins: C3a and C5a. Adv. Immunol. 26, 1.

van Kessel. K.P.M.. Antonissen. A.C.J.M.. van DiJk, H.. Rademaker, P.M. \& Willers, J.M.N. (1981) Interaction of killed Listeria monocytogenes with the mouse complement system. Infect. Immunol. 34, 16.

LOOR. F. (1980) Plasma membrane and cell cortex interactions in lymphocyte functions. Adv. Immunol. 30. 1.

MolenaAr. J.L.. Muller. M.A.C., Engelfriet, C.P.\& Pondman. K.W. (1974) Changes in antigenic properties of human $C 3$ upon activation and conversion by trypsin. J. Immunol. 112.1444.

Molendijk, W.J. Ploemacher. R.E. \& Erkens-Verstuis, M.E. (1982) Mediatory role of stem cells derived cells in LPS-induced splenic CFU-s accumulation. Exp. Hematol. 10, 499.

Perez. H.D. \& GoldSTEIN. I.M. (1981) Regulation of the biologic activity of C5-derived peptides. Adv. Inflamm. Res. 2.1.

Ploemacher. R.E.. Erkens-Versluis. M.E.. Paques, M.. Wilschut, I.J.C. \& Vos, O. (1980) Effects of serum complement levels on the mobilization of mature white blood cells in relation to mobilization of CFU-s. Exp. Hematol. 8. 826.

Quesenierry, P.J.. Morley. A.. Ryan, M.. Howard. D. \& Stohlmann, F. (1973) The effect of endotoxin on murine stem cells. J. Cell Physiol. 82. 239.

Rickaro. K.A.. Rencricca. N.J.. Shadduck. R.K.. Monette, F.C., Howard, D.E.. Garrity, M. \& Stohlmann. F. (1971) Myeloid stem cell kinetics during erythropoietic stress. Br. J. Haematol. $21,537$.

Ross. W.M.. FLiedner. T.M.. Körbling. M. \& Notdurft, W. (1976) Mobilization of hemopoietic stem cells by dextran sulphate into peripheral blood (dogs). Exp. Hematol. 4, suppl., 52.

ROSEN. F.S. (1975) Immunodeficiency. In: Immunogenetics and Immunodeficiency (Ed. by B. Benacerraf), p. 230. MTP, Lancaster.

Snyderman. R., Shin, H.S., Phillips. J.K., Gewurz, H. \& Mergenhagen, S.E. (1969) A neutrophil chemotactic factor derived from $\mathrm{C} 5$ upon interaction of guinea pig serum with endotoxin. J. Immunol. 103. 413 . 
Snyderman, R., Shin, H.S. \& Hausman, M.H. (1971) A chemotaxtic factor for mononuclear leukocytes. Proc. Soc. Exp. Biol. Med. 138, 387.

StABER, F.G. \& JohNSON, G.R. (1980) The responses of hemopoietic precursor cells in mice to bacterial cell-wall components. J. Cell Physiol. 105, 143.

TILL, J.E. \& MCCULLOCH, E.A. (1961) A direct measurement of the radiation sensitivity of normal mouse bone marrow cells. Radiat. Res. 14, 213.

Vos, O., Buurman, W.A. \& Ploemacher, R.E. (1972) Mobilization of haemopoietic stem cells (CFU) into the peripheral blood of the mouse; effects of endotoxin and other compounds. Cell Tissue Kinet. 5, 467.

Vos, O. \& WILSChUt, I.J.C. (1979) Further studies on mobilization of CFU-s. Cell Tissue Kinet. $12,257$.

Wilschut, I.J.C., Erkens-Versluis, M.E., Ploemacher, R.E., Benner. R. \& Vos, O. (1979) Studies on the mechanism of haemopoietic stem cell (CFU-s) mobilization. A role of the complement system. Cell Tissue Kinet. 12, 299. 